\title{
Article \\ Translation or Divination? Sacred Languages and Bilingualism in Judaism and Lucumí Traditions
}

\author{
Michael Nosonovsky
}

check for updates

Citation: Nosonovsky, Michael. 2022. Translation or Divination? Sacred Languages and Bilingualism in Judaism and Lucumí Traditions. Religions 13: 57. https://doi.org/ 10.3390/rel13010057

Academic Editors: Cyril S. Aslanov and Jeff Levin

Received: 22 November 2021

Accepted: 4 January 2022

Published: 7 January 2022

Publisher's Note: MDPI stays neutral with regard to jurisdictional claims in published maps and institutional affiliations.

Copyright: (C) 2022 by the author. Licensee MDPI, Basel, Switzerland. This article is an open access article distributed under the terms and conditions of the Creative Commons Attribution (CC BY) license (https:// creativecommons.org/licenses/by/ $4.0 /)$.
College of Engineering and Applied Science, University of Wisconsin-Milwaukee, Milwaukee, WI 53211, USA; nosonovs@uwm.edu

\begin{abstract}
I compare the status of a sacred language in two very different religious traditions. In Judaism, the Hebrew language is the language of liturgy, prayer, and the Written Law. The traditional way of reading Torah passages involved translating them into Aramaic, the everyday language of communication in the Middle East in the first half of the first millennium CE. Later, other Jewish languages, such as Yiddish, played a role similar to that of Aramaic in the Talmudic period, constituting a system referred to as the "Traditional Jewish Bilingualism". Hebrew lexemes had denotations related to the realm of Biblical texts, while Aramaic/Yiddish lexemes had everyday references. Therefore, the act of translation connected the two realms or domains. The Lucumí (Santería) Afro-Cuban religion is a syncretic tradition combining Roman Catholicism with the Ifá tradition, which does not have a corpus of written sacred texts, however, it has its sacred language, the Lucumí (Anagó) language related to the Yoruba language of West Africa. While the Spanish-Lucumí bilingualism plays an important role in Santería rituals, the mechanisms of reference are very different from those of the Hebrew-Yiddish bilingualism in Judaism. In Santería, divinations about the meaning of Lucumí words play a role similar to the translations from Hebrew in Judaism. I further discuss the role of ritual dances in Santería for the transition from the sacred to the secular domain and a function of Hebrew epitaphs to connect the ideal world of Hebrew sacred texts to the everyday life of a Jewish community.
\end{abstract}

Keywords: Hebrew; Yiddish; Santeria; Lucumi; Anago; Yoruba; Traditional Jewish Bilingualism; Afro-Cuban

\section{Introduction}

In this article, I will compare the attitude towards holy languages in two very different religious traditions. In Judaism, a religion with a vast corpus of sacred texts, Hebrew is considered a sacred or holy language (Lashon ha-Qodesh ${ }^{1}$ in Hebrew or Loshn-Koydesh in Yiddish). Biblical Hebrew (BH) was the language of the Torah or the Written Law. The Mishnaic Hebrew of the 1st-2nd centuries CE was a language of codification of the Jewish law. The Medieval or Rabbinical Hebrew was used as a written language for various needs of written communication and various purposes including liturgy, prayers, study, and scholarship. In various Jewish communities throughout the world, the degree of knowledge of Hebrew was different; however, in many cases, it was studied in a traditional society by the majority of school-age boys who attended elementary schools (hadarim).

Side-to-side with Hebrew, a spoken Jewish language existed, often forming a complex symbiosis with the Hebrew language, with many lexical units often being borrowed from Hebrew and co-existing with native words forming a separate (often high) register. The degree of merging Hebrew words with Yiddish could vary, forming at least two separate registers: the Whole Hebrew and the Merged Hebrew (Weinreich 2008). Thus, the BH word שבת šabba:t (Saturday) would be pronounced in Ashkenazi Hebrew (Whole Hebrew) as shabos, while in Yiddish (Merged Hebrew) as shabes. Yiddish was often considered “women's 
language" since usually women had a much lower degree of knowledge of Hebrew in a traditional society.

The Judeo-Aramaic language of the Talmud (or more exactly, of the Gemarah, which is a major part of the Talmud) was referred to as the Leshon-ha-Targum (literally, "the language of translation") and it was viewed as the language of the Oral Law. A translation from Hebrew to Aramaic had a hermeneutic significance by itself. Thus, a suggested way of reading the Torah verses was "twice the Scripture, once the [Aramaic] translation." Translating a part of a text from the holy language relates the realities of the realm of the sacred texts, such as the Bible, to the realities of everyday life. Moreover, simple borrowing a lexeme from the Hebrew language brings denotations and connotations from the sacred texts to everyday life realities. We will investigate it more in detail using Hebrew epitaphs as an example.

Similarly to Judaism, Santería (literally, the religion of the Saints or the Orishas) is a diasporic religion that developed during the late 19th century among the Afro-Cuban population of Cuba (González-Wippler 2002). While being syncretized with Roman Catholicism, the central aspect of Santería (also called Lucumí) is the cult of deities called Orishas originating in the West African Yoruba tradition of Ifá. In Cuba, Orishas have become identified with Catholic saints (Clark 2001). Among the most important Orishas in the Santeria I Ifá pantheon are Olodumare (the supreme god creator of the universe), Olorun, and Olufa who are syncretized with the Christian Holy Trinity, as well as seven "African powers Orishas" including Eleguá, Obatala, Oggun, Chango, Yemaya, Ochun, and Babalu-Aye (the latter is replaced by Orunmila, a god of wisdom and divination, in the African Ifá tradition) ${ }^{2}$.

Interestingly, many followers of Santeria describe it as a monotheistic religion, with one Supreme God (Olodumare), while orishas are viewed as spirits (or sometimes even interpreted as archetypes of the human conscience) rather than as gods. There are several Santeria traditions including the Regla del Ocha (the Rule of Ocha, with "Ocha" being another word for orishas), where initiated priests and priestesses are called santeros and santeras and the Ifá tradition, where the priests (only male) called Babalawos (the fathers of mystery).

Santeria apparently was formed as a crypto-religion among black slaves belonging to the communities (cabildos de nación) of Yoruba descent in colonial Cuba. After slavery was abolished in 1886 and following Cuba's independence in 1902, Santería became an officially recognized religion (González-Wippler 2002).

Unlike Judaism, Santería does not have a canonical corpus of written texts. All sacred texts are transmitted in the oral form. However, there is a sacred language or quasilanguage, the Lucumí language, used during various rituals including divinations, which play a central role in Santería. Lucumí-Spanish bilingualism has an important function in Santería, and I will discuss it in detail. Interestingly, religious dances play a significant role in Santería rituals. Most Orishas, both male and female, have their dances with a certain dancing quasi-language. These religious dances have affected the secular genres of Cuban and Latin dances such as Salsa, Son, and Timba.

\section{Bilingualism and Translation in Judaism}

\subsection{Hebrew-Aramaic Bilingualism and Its Traditional Interpretation}

A theory of the Hebrew-Aramaic bilingualism or diglossia was elaborated by several significant Rabbinical authors and kabbalists, who recognized the importance of the coexistence of Hebrew perceived as the language of the Written Torah and Aramaic percieved as the language of the Oral Torah. Hebrew is called in traditional sources קודש לשון LashonQodesh ("the sacred language"), while Aramaic is called תרגום לשון Lashon Targum ("the language of the translation").

One should note that this distinction only partially reflects the situation. Some parts of the Hebrew Bible, such as parts of the Book of Daniel and Ezra, are written in Biblical Aramaic, the form of the Imperial Aramaic. On the other hand, the Hebrew language was used in the Babylonian Talmud (BT) along with the Judeo-Aramaic of the BT. Another note is that the term Targum in its meaning of the Judeo-Aramaic translation of the Biblical Text 
(e.g., Targum Onkelos and Targum Jonatan) should be distinguished from targum as an oral rendition of the biblical text in an Aramaic translation, as well as from the general meaning of the Hebrew word targum as "translation" (from or to any language).

The BT suggests that Torah verses are supposed to be studied three times ואחד תרגום "Twice the Scripture, once the [Aramaic] Translation (rendering)." Thus BT, Berachot 8a says "Rav Huna bar Yehuda said that Rabbi Ami said: A person should always complete his Torah portions with the congregation. The congregation reads a particular Torah portion every Shabbat, and during the week before each Shabbat, one is required to read the Bible text of the weekly portion twice and the translation once." The ability to translate or render a text from the sacred language into a spoken language constitutes an important level of understanding the text.

According to some medieval Rabbis and Kabbalists, the Aramaic language was viewed as ant intermediate layer between the Hebrew language and the so-called "seventy languages of the peoples of the world" (according to a traditional view, there are seventy nations in the world). Thus Rabbi Isaiah Horowitz (Shelah ha-Qadosh, 1565-1630), a significant author of the Lurianic Kabbala suggested that the Aramaic language corresponds to the intermediate layer נגה קליפת (Qelippat Nogah) between the holy and the profane (Nosonovsky 2017).

Rabbi Horowitz investigates the statement in Gemara suggesting that the "Ministering Angels" (השרת מלאכי) do not understand the Aramaic language and therefore the prayer "Eighteen Blessings" could be recited in any language except Aramaic. He suggests that the reason is that otherwise there would be a temptation to equate the status of the Aramaic language with that of Hebrew:

"A King can talk about his personal needs to his servants. However the king would rarely talk to his ministers, and if he talks to them, then it is only in a royal manner so that nobody would think that they are equal to him. About the servants, nobody would assume that they are equal to the King, so there is no concern. Therefore, the ministering angels can understand every language and there is no concern [that it would be equated to the Hebrew language], but with the Aramaic language, there is a concern" (Shelah, Pesahim, Matza Shemura).

Another prominent Kabbalist, Rabbi Judah Loew ben Bezalel (also known as the Maharal of Prague, d. 1609) developed an elaborated theory, according to which the Aramaic language is a universal language of mankind, which does not belong to any particular nation (among the "seventy nations of the world"), whereas Hebrew is a particular language of the Jewish people. Of course, the Aramaic language at some point was the language of Arameans. However, by the time it become known to the ancient Jews, namely, by the sixth century BCE, the Arameans had disappeared from the historical scene. The so-called Aramaic language became the official language and lingua-franco in the Persian Achaemenid Empire. This is perhaps why Aramaic was perceived as a common language rather than a language of any particular nation.

In his commentary Hiddushe Aggadot on BT Treatise Sotah 33a, the Maharal writes:

"May the Prayer [=Eighteen Blessings] be recited in any language? Behold Rab Judah has said: A man should never pray for his needs in Aramaic. For R. Johanan declared: If anyone prays for his needs in Aramaic, the Ministering Angels do not pay attention to him, because they do not understand that language!'” (Sotah 33a)

"The principal meaning is that the Ministering Angels do not understand the Aramaic language at all, as it is not even called 'a language'. As I explained on Megilla 10b on 'And I took a name from Babylonia ... ,' they do not have writing and language. The Aramaic language is not a part of the seventy languages, although it is a language, it is not among the seventy created by the Holy One, blessed be he. Why is Aramaic not among the seventy languages? Because it is said in Sukkah 52a about the Chaldeans that 'they will not be a people' ... The 
Torah paid respect to the Aramaic language; however, it does not belong to the seventy languages of the peoples of the world. This is because among the angels there are seventy appointed as ministers over the peoples of the world, however, the angels have no connection to the Aramaic language."

The Maharal further claims that Aramaic was the language of Adam, the first human, and therefore this language is universal. Moreover, the Maharal believed that the Aramaic language is the language of the messianic future "world-to-come," explaining the rule "the Scripture twice, the [Aramaic] Translation (Targum) once":

"The Translation [=the Aramaic language] has the aspect of the World to Come because it is not considered a language at all, as it is said 'And I took a name from Babylonia ... ' (Megilla 10b) about the Chaldeans who have no writing and language of their own. As we explained in a different place, the Aramaic language or the language of Babylonia is not considered a language. Its essence is thought, and the thought corresponds to the highest degree of the World-To-Come. This corresponds to 'Translation once'. In addition, the Ministering Angels do not understand Aramaic, and 'Translation once' corresponds to the World-to-Come, as it is known that it belongs to Israel and not to the angels (Tiferet Israel, 13).

'Rabbi Juda said on behalf of Rava: Adam, the first man, spoke Aramaic' (Sanhedrin 38b) The meaning is that neither the Holy Language nor the rest of the seventy languages were appropriate for Adam. Because the Holy Language is a particular language of one nation, and the seventy languages as well. For Adam to master every language that originated from him, a particular language was inappropriate. However, he had the Aramaic language (Hiddushe Aggadot).

Another prominent Kabbalist and the founder of the Breslov Chassidism movement, Rabbi Nachman of Breslov (1772-1810) suggested that the world was not created in a perfect state in order to leave for man the possibility to finish the divine work and to give man the ability to improve the world, thus participating in the creation of the world together with the Lord (Liqute Moharan 1:19). Moreover, according to Rabbi Nachman, this is similar to how a baby boy is born uncircumcised and thus "imperfect," so a circumcision ritual should be performed. Only when accompanied by the Targum (the Aramaic translation), the holy language would become perfect. According to this line of thought, Biblical Joseph had a perfect knowledge of Hebrew, which involved the ability to translate into other languages. This is indicated by Joseph's ability to interpret dreams, and a Kabbalistic hint here is that the word תרדמה tardema ("dream") has the same numerical value (gematria) as the word תרגום targum ("translation").

Other Chassidic Rabbis claimed that in modern times, Yiddish played the same role as Aramaic in the time of Talmud. The Rebbe Israel Dov-Ber from Vilednik (1789-1850) said that by filling the Germanic language with Hebrew words (which is the case in Yiddish) the Jews bring holiness to a non-Jewish language and thus accelerate the coming of the Messiah (Shearis Israel, Zemanim, Shavuot 6).

\subsection{Hebrew-Yiddish Bilingualism}

In the previous section, I discussed the traditional approach the Jewish bilingualism, which implied three types of languages (Hebrew-Aramaic/Yiddish-non-Jewish "70 languages"). In this section, I will elaborate on academic linguistic concepts of Hebrew-Yiddish bilingualism and diglossia. While Judeo-Aramaic of the Babilonian Talmud was a Semitic language, Yiddish is a Germanic language separated by centuries from the Talmudic epoch. A pioneer of Yiddish linguistics, Max Weinreich (2008), has suggested the concept of the "Chain of Jewish Languages," including Judeo-Aramaic, Judeo-Greek, Judeo-Romance, and Judeo-German (Yiddish), stressing the typological similarities of these different languages. 
Weinreich has also suggested the sociolinguistic concept of Traditional Jewish Bilingualism (TJB) (Weinreich 2008). According to Weinreich's theory, two co-existing Jewish languages, such as Hebrew and Yiddish, possess two different sociolinguistic functions. In an ideal TJB scheme, Hebrew was a language that served predominantly for written communication. Therefore, besides being a liturgical language, Hebrew serves such purposes as Torah studies, scholarly and exegetic work, as well as to the needs of practically written communications including the correspondence, bookkeeping, communal record-keeping (e.g., the so-called pinkasim or books of records of various communal institutions).

On the other hand, in the ideal TJB scheme, Yiddish is a language of predominantly oral communication. This TJB scheme best applies to the pre-modern Jewish society of Eastern and Central Europe. The actual or real scheme of the TJB may be different from the ideal one in that on rare occasions Hebrew is used for oral communication, while Yiddish is used for writing, including various notes and entertainment literature mostly intended for Jewish women and less-educated men and thus considered not serious.

Hebrew was considered a men's language, as almost all boys learned it in a heder, an elementary school, whereas Yiddish literature was considered of interest for women, who were usually not proficient in Hebrew and thus unable to participate in Hebrew written communication. Yiddish was therefore called a mameloshn (mother's language) while Hebrew was associated with the culture of Talmudic and rabbinical studies.

Note that Yiddish itself includes a significant Hebrew component, in addition to its Germanic and Slavic components. Although Hebrew and Yiddish constitute two distinct languages - the first one is a Semitic language, whereas the second one is a Germanic language - there are known many forms of texts which could be considered a mixture or even an intermediate between pure Hebrew and Yiddish. These are either Hebrew texts with a large number of words borrowed from Yiddish, or Yiddish texts "enriched" by many words belonging to the Hebrew component of Yiddish. Examples of such texts would include the so-called Scribal Yiddish (the language of some communal documents written in Yiddish with about $50 \%$ or more Hebrew inclusions), secret languages or "cryptolects" of some merchants (e.g., Lakudesh of late medieval/early modern cattle traders in Germany), the language of Talmudic discussion, rich of Hebrew lexicon, and many others.

Moreover, since Yiddish has a significant Hebrew component (from 10\% to 25\% of its vocabulary, according to various estimates), in a certain context, almost every Hebrew word or expression can be used in Yiddish. Therefore, while a sophisticated linguistic conceptual apparatus has been developed including such concepts as "Whole Hebrew vs. Merged Hebrew", it is sometimes impossible to distinguish between a "foreign" Hebrew word borrowed in a Yiddish text from a "native" Yiddish word of Hebrew origin (Shapira 2010).

Although Hebrew and Yiddish both use Hebrew letters, they employ a radically different orthography. Hebrew orthography is a consonant one with letters representing only consonant phonemes (with some exceptions). Yiddish developed a phonemic orthography with letters representing both consonant and vowel phonemes and/or sounds. Thus, the Hebrew letter 'ayin in Yiddish designates [e], the letter kometz-alef designates [o], pasahtzvey-yuden is [ay], and so on. Despite that, orthography can hardly be an indicator of whether the word is in Hebrew or Yiddish. This is in part because the Yiddish lexica of the Hebrew component are written in Hebrew orthography (despite being a part of Yiddish). Furthermore, Yiddish orthography is used in Ashkenazi Hebrew texts when foreign words of non-Yiddish origin are used (Nosonovsky 2008a).

\subsection{Case Study: Hebrew Epitaphs from Eastern Europe}

We see how the idea of translation from the holy language is related to the more general concepts of the actualization of a sacred text and its interpretation. It is interesting to consider this concept using the example of Hebrew epitaphs or gravestone inscriptions.

Gravestones with Hebrew inscriptions are the most common class of Jewish monuments still present in such regions as Ukraine or Belarus (Nosonovsky 2008b). The genre 
of Hebrew epitaphs seldom becomes an object of cultural or literary studies. Previously, we have shown that one function of Hebrew epitaphs is to connect the ideal world of Hebrew sacred texts to the world of everyday life of a Jewish community (Nosonovsky 2009).

Traditional epitaphs are written in Hebrew. Inclusions in other languages are rare, except for rabbinical Aramaic expressions. Epitaphs are seldom written in Yiddish since Yiddish was the household language and epitaphs were not meant for idle reading. Having said that, Yiddish, which was the mother tongue for the authors of Hebrew inscriptions, is sometimes discernible through this Hebrew. Whenever they needed to refer to a phenomenon with no equivalent in the sacred Hebrew books, for example, a place name or a family name, they would switch to the typical Yiddish orthography.

The language of the epitaphs is not Biblical Hebrew but is rather a set of standard Hebrew formulas. In the TJB scheme, Hebrew was the language of Scriptures referring to the realities of the holy books, while Yiddish served as the household and communal language of everyday life (Weinreich 2008, p. 247). In a traditional Jewish society, Hebrew and Yiddish were not always opposed to each other but existed in close symbiosis. In the period preceding modernization, the Hebrew language (studied from the sacred books) served to denote "bookish" realities and references, while Yiddish (used in everyday life) served to denote everyday realities. This explains several features of switching between the phonetic and consonant spelling in epitaphs (Nosonovsky 2008a, pp. 53-76).

Hebrew epitaphs express the idea of a connection between the "sacred" world of Scripture and religious Hebrew books and the world of everyday life of a shtetl or community. This can be traced at several levels. First, at the level of the inscriptions' structure, the epitaph includes an indication of the place (נטמן פה "here lies"), time (date), and name, thus tying the deceased to a specific "coordinate system". Second, biblical quotations emphasize the relation of a particular life and death to the situation described in the Bible. Third, at the language level, even though epitaphs are almost always written in Hebrew and not in Yiddish, we are dealing with certain features of Hebrew-Yiddish bilingualism. Hebrew terms could simultaneously be Yiddish lexemes. We observe orthography code-switching between Hebrew consonant spelling and Yiddish phonetic spelling, depending on whether the concept is found in Hebrew holy books or everyday life. Fourth, epitaphs occupy an intermediate position between the "high", author's literature, and canonical religion, on the one hand, and folk literature and religion, on the other hand (Nosonovsky 2017).

Let us elaborate on orthography code-switching. The traditional Hebrew (consonant) orthography is used for words and concepts of Biblical origin, while the phonetic or phonemic (Yiddish) orthography is used for profane or non-biblical realities. Example:

יעקב 'במ משה מהורר התורני שטערקבערגר

Figure 1a. "A Torah man, R. Moses son of Jacob Shterkberger" (1666 CE, Trostyanec). In the Germanic family name Shterkberger, the letter 'ayin is used for [e] (not שטרקברגר as it would be spelled in accordance to the consonant Hebrew orthography).

An interesting example of how different orthographies relate to the sacred texts to the yday life is found in one of the oldest Ashkenazi inscriptions from Eastern Europe, the 1520 CE epitaph from Busk (Nosonovsky 1999),

נתן פּאר תחת אפ̄ר כי פּה נטמן איש נאמן ר' יהודא בן ר' יעקב דמתקרי ליודא

Figure 1b. "Gave jewelry instead of the ash (cf. Is 61:3), because here lies a reliable man, R. Yehuda, son of R. Jacob, who was nicknamed Ide" (Busk, year 1520).

Ide and Yehuda (often spelled יהודא with 'aleph to avoid a combination of letters constituting the God's name) are essentially the same names. Although in accordance to the Modern Hebrew pronunciation they would be pronounced differently, the Ashkenazi Hebrew dialect reading would be the same. The juxtaposition of these two names makes sense only as a written (not oral) comparison between (Biblical) יהודה and from Busk. 


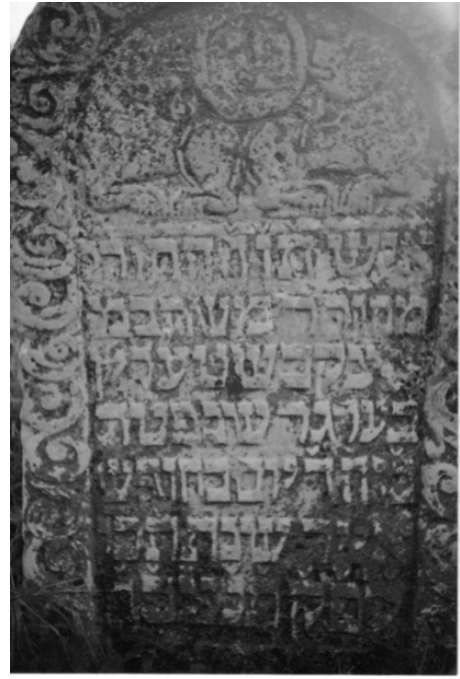

(a)

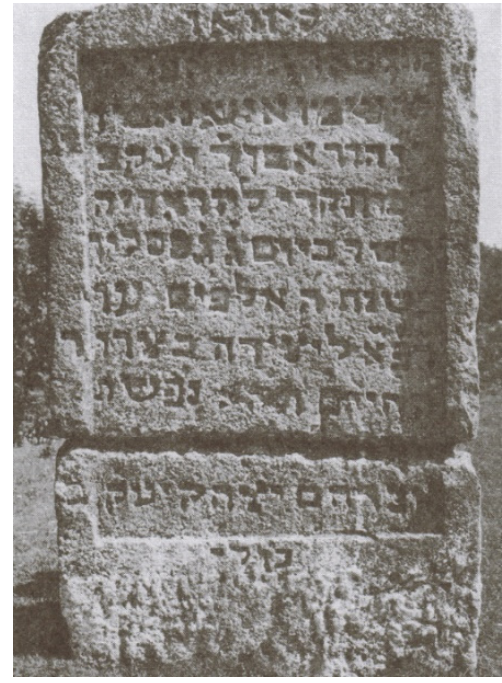

(b)

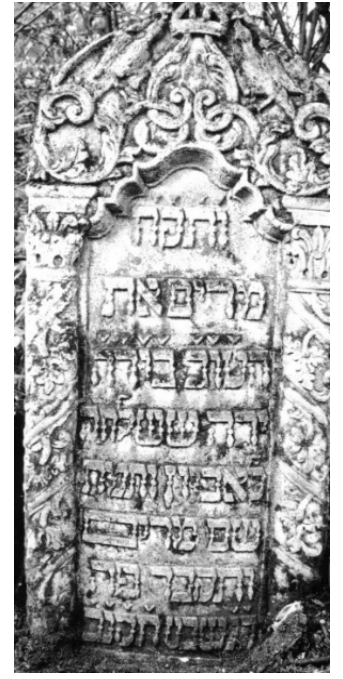

(c)

Figure 1. Jewish gravestones with Hebrew inscriptions from Ukraine. (a) Moses Shterkberger, 1666 CE, Trostyanec (b) Yehuda (Ide), 1520, Busk (c) Miriam, 1792, Buczacz (photo by M. Kheyfets).

The choice between the Hebrew or Yiddish orthographies marks whether a particular word (and realities designated by the word) are found in the Hebrew sacred text or the word is only related to everyday mundane reality.

Biblical verses can be cited in Hebrew epitaphs. Quite often, a verse mentioning a Biblical character with the same name as the deceased is cited. Below is an example of an epitaph from the town of Buczacz (1792 CE),

ותקח מרים את הטוב בידה ידה ששלחה לאביון ותנוח שם מרים תקבר פה ד"ג שבט תקנ״ב

Figure 1c. "And Miriam took the good in her hand, the hand that she prostrated to the poor, and Miriam died there, and she was buried here 23 Shevat (5)552".

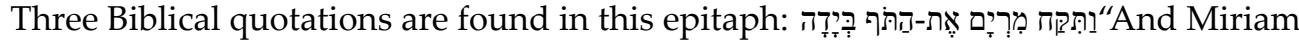
took ... the drum in her hand" (Ex 15:20), poor" (Pr 31:20), which means she was generous in giving charity; the verse is from the

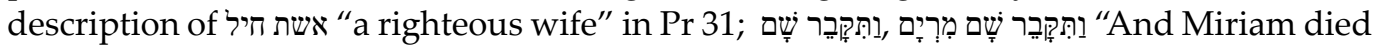
there and was buried there" (Nm 20:1).

In the example above, the purpose of the first quotation is to compare Miryem from Buczacz with Biblical Miriam. The word ๆ tof ("drum") is substituted by a similarly sounding word טוב tov ("good"). The second quotation from the popular liturgical poem ("a righteous wife") based on Pr. 31, which is recited on Saturday Eve, stresses that this Miryem from Buczacz was a righteous wife like a Biblical ideal. The third verse compares the death of Miryem from Buczacz with that of Biblical Miriam, with the word

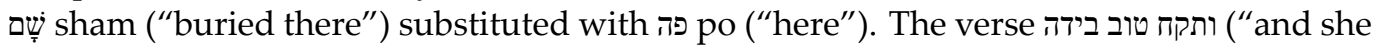
took good in her hand") constitutes a chronogram which yields the year 552 from the Creation or 1791/2 CE when numerical values of the letters are summed up. This complements the regular way of indicating the year תקנ"ב.

Thus we observe the same pattern of the actualization of a sacred text, or the bridging between the realm of the sacred texts and the realm of everyday life, whereas the epitaph constitutes a tool to construct such a bridge.

Thus, Hebrew, the sacred language, represents the realm of the ideal concepts, while Yiddish represents the realm of everyday life. Translation between these two languages connects the two worlds. 
Note that an epitaph is often not the only part of the traditional gravestone. In some cases, monuments include also illustrative elements. An example would be the image of a ship on the monument of Malka Babad (1837 CE in Brody) who traveled to Palestine in the early 19th century (Figure 2a). According to her poetic epitaph, "in her young years, she left the vanity of the world and took her soul into her hand to sail on a mighty ship to the place of the Beth-El [= the Temple]." The expression "Mighty Ship" (אדירצי) originates from Isaiah 33:21, and thus the carved image illustrates the Biblical concept.

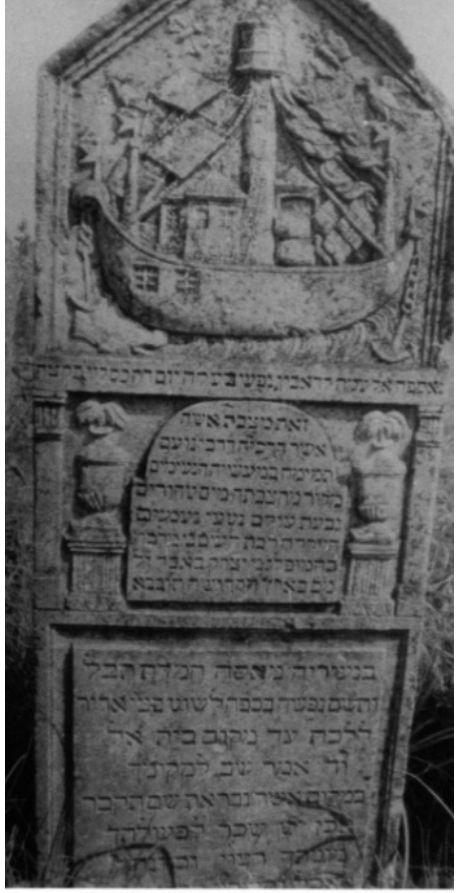

(a)

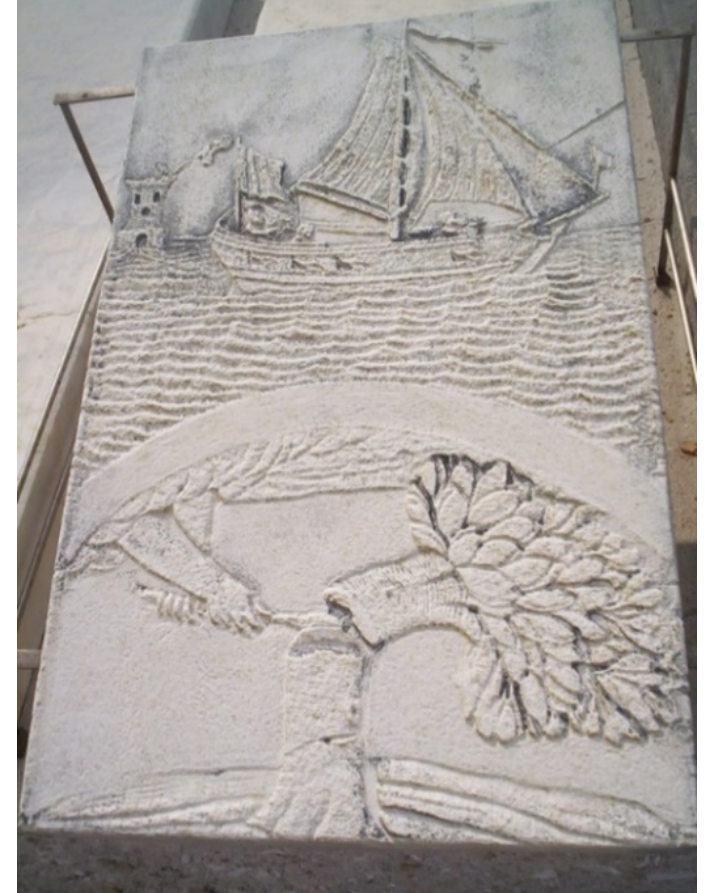

(b)

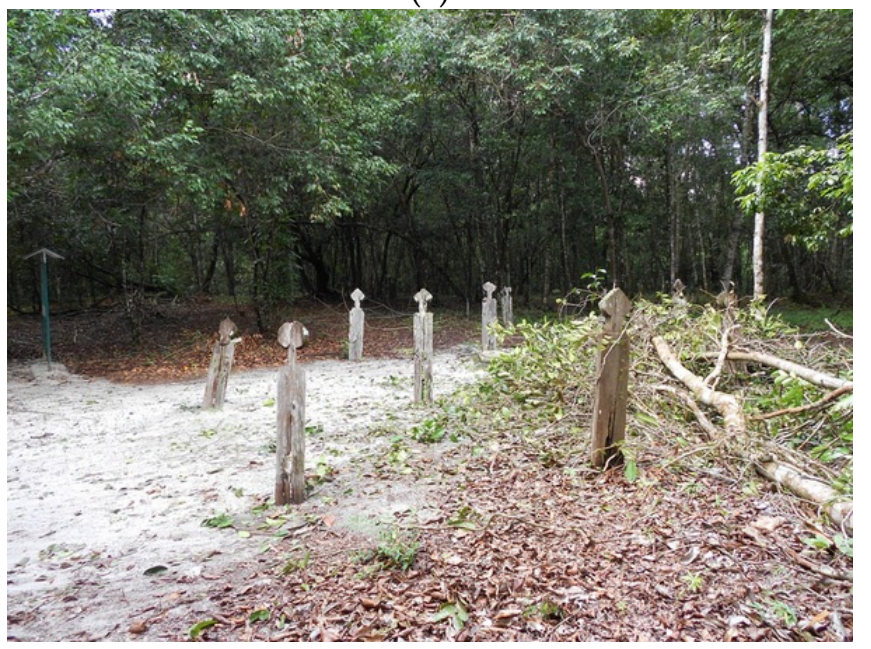

(c)

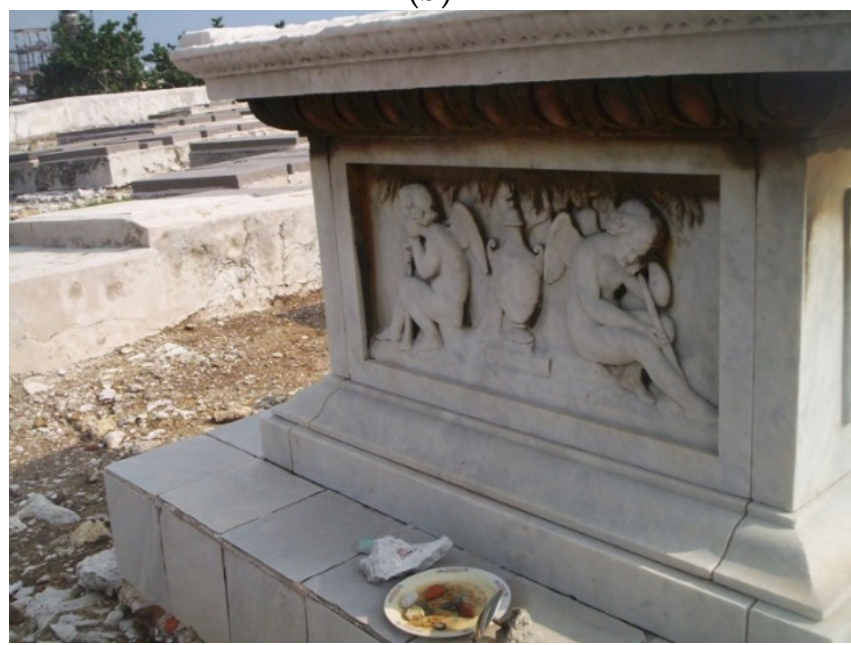

(d)

Figure 2. (a) Malka Babad's gravestone (Brody, 1837). (b) A Jewish gravestone with an image of a ship in Curaçao. (c) Creole cemetery in Jodensavanne, Suriname. (d). In Curaçao, the old Jewish cemetery, according to the leader of the local Jewish community, Rene Maduro, in some cases became a place of voodoo rituals (Figure 2d, taken by the author in 2006). 
The image of a ship is also found on some Jewish gravestones in Amsterdam and of the colonial Dutch communities such as Suriname and Curaçao (Figure 2b), where it likely symbolizes the trans-Atlantic trade. Compare with "she is like a merchant's ships" (Proverbs 31:14). A journey by water can also symbolize death itself.

In the next section, we will consider the Afro-Cuban tradition of Santería.

\section{Bilingualism in the Lucumí/Santería Tradition}

In the previous section, we discussed how translation connects the sacred and mundane worlds or realms in the monotheistic Jewish religious tradition, which is based on a large corpus of written texts. The Santería polytheistic tradition has a radically different structure. Consequently, and the same objective of connecting the sacred and mundane is achieved by different means.

Yoruba is a Niger-Congo language, which is not directly related to the Afroasiatic language family, to which Hebrew language belongs. Certainly, some typological similarities in attitudes towards mystical ideas included those discussed by Bohak (2007) and Walter Benjamin (Miller 2016), are possible ${ }^{3}$.

\subsection{Is Lucumí a Language?}

It is often claimed that the sacred language of the Santería religion is the Lucumí language. However, at first, we should consider the question of whether Lucumí is a language at all. Some scholars define Lucumí as "a lexicon of words and short phrases derived from the Yoruba language and used for ritual purposes in Cuba and the Cuban Diaspora; it is used as the liturgical language of Santería in Cuba" (Brandon 1997; Wirtz 2014; Villepastour 2019). A lexicon of words does not amount to a full-scale language, since it misses essential components of a language, such as elaborated syntax and recursive organization, and because its functional domain is limited.

Other researchers, however, insist that Lucumí is a language. M. Concordia (2012) suggested that Lucumí (Anagó) language is "a functional vehicle for the transmission of ideas and culture and is an irreplaceable cultural component of the Lucumí community." (Concordia 2012, p. 2). She insists that Lucumí is a language with a status similar to that of the Latin language in Catholicism. After all, ritual or liturgical languages exist in many cultures: Hebrew in Judaism, Latin among Catholics, Church Slavonic among Orthodox Slavs, Arabic in Islam, Sanskrit in Hinduism, etc. However, there is a nuance with Lucumí. Unlike Latin, Hebrew, or Church Slavonic, it is not a written language. There is no canonical corpus of sacred scripture in Santeria because all texts were transmitted orally. The first official publication of the text on Lucumí, The Book of Diagnosis in Ifá Divination, was published around 1950, and publications in Lucumí are rare.

Moreover, the relationship between a high and a low language, which is a characteristic of a diglossia, is complicated in the case of Lucumí and Spanish. This situation confuses sociolinguists who are accustomed to the more traditional classification of languages. M. Concordia compares it with the relation of the Latin and Spanish languages in Catholicism:

"Latin would always have a higher prestige whereas Anagó only temporarily has prestige within the community of Anagó speakers during ritual actions and ceremonies. This is because Anagó is identified with a lower social class and therefore may also stigmatize the speaker creating tension. Therefore within a limited community, such as during a ritual, Anagó temporarily ascends to a higher position, and Spanish which is the dominant language, comes the low variety. This makes the classification of Anagó speakers difficult in terms of diglossia or bilingualism." (Concordia 2012, p. 87)

In addition to the ritual status of Lucumí, it can be viewed as a contact language or one of the creolized dialects of Spanish. Bozal is the term which is often used to refer to a hybrid contact language spoken by Africans who have been in contact with Spanish traders. Bozal is sometimes defined as "Spanish spoken imperfectly by slaves born in Africa." (Lipsky 
1987, p. 431). Some linguists even suggest the term Lukuñol as a hybridization of the words Lucumí and Español (Spanish). Thus, to a certain extent, Lucumí was preserved in the Spanish version used by the Afro-Cubans.

Cuban versions of the African Yoruba language can also be used in situations not directly related to religion, such as songs or poetry. However, the main use of Lucumí is in the Santeria ritual. Ritual texts such as patakín (fables or moral stories), refrán (sayings), and oriki (prayers of praise) must include Lucumí elements to be valid for the Santeria religious community. Despite that, it is not uncommon for practitioners to add Spanish words to their prayers when they find it difficult to use the Lucumí terminology.

Amanda Villepastour (2011) suggested that deliberate Yorubization of Lucumí played a role in contemporary retranslation and circulation of Lucumí songs for the orishas among devotees and scholars in Cuba.

M. Concordia claims that the use of Lucumí reflected the belief of the followers of Santeria in the magic of words. In the Yoruba culture, there is a concept of vitality, aché (àse in modern Yoruba spelling), in many respects similar to the concept of the living force in other cultures, such as the Chinese 氣 Qi, or the concept of mana among the aborigines of the Pacific Islands. It is appropriate to recall both the Greek pneuma and élan vital of Henri Bergson and many other incarnations of this theory of the "life force" that animates all living things. The concept of ache is related to the concept of the power of the word, bara. M. Concordia refers to Olaoluwa Fasadé, who writes:

"Within the belief system of Yoruba culture, there is the overwhelming belief in the divine power of the word ... bara is the power of creative speech. Bara is the power that sets life force (ase) in motion." (Concordia 2012, p. 85)

How is the Lucumí language preserved and transmitted among the followers of Santeria? M. Concordia notes that Akpuon and Obá Oriáte were key transmitters of the ritual language. Akpuon is a master of songs or a master drummer (omo anya), who leads the congregation during the drumming and dance ceremonies. The phonetics of the tonal Yoruba language is imitated by the bata drum tone language, with different drum sounds to imitating sacred speech. Akpuon must remember thousands of songs and know the meaning of each of them. It is his responsibility to cast spells correctly to ensure that the orisha deities are invited to attend the ceremony. These songs and spells must be sung or chanted in Lucumí (Concordia 2012, p. 88).

Obá Oriáte serves a similar function. He must know all the songs and spells that make up the initiation ceremony and other rituals. Both must remember thousands of oriki (prayers of praise), súyeres (chants), orin (songs), and refránes (proverb), understanding their meaning (Concordia 2012, p. 90).

\subsection{Connecting Sacral and Mundane by Divination}

Divination rituals play a central role in Santería practices. The divination method used in Santeria and many other Yoruba-based spiritual systems is the so-called Odu Ifá divination. This system is based on the hexadecimal number system, which makes it, to some extent, similar to the representation of data in modern computers, where one byte (eight bits) of information is the major unit allowing 256 combinations of variants.

During the divination ritual, a santero/a usually throws sixteen Dilogún shells. Each shell can fall out with either its convex or concave side on the top, giving a total of 256 variations called ode signs (technically, they are composed of sixteen "basic odes" repeated twice). The signs are associated with specific orishas. An initiated diviner remembers by heart many stories (Patakís) associated with each sign. As a result, a story is selected that matches the client's situation or his problem (Fernandez 2014, p. 43).

For day-to-day use, Babalawo uses a simpler setup, the ékuele (or opele) fortune-telling chain, consisting of eight Ikin palm nut shells, each of which can lie on one of two sides, giving a total of 256 variations (Figure 3). It is believed that the ékuele establishes a connection with Orunmila (Orunla), the orisha of wisdom and knowledge. A legend states that 
originally Ékuele was Orunla's quarrelsome wife, who questioned his predictions and incited Ifá priests against him. As a punishment, Orunla imprisoned her soul with a chain, but she managed to grab and take with her the souls of her eight children. This is how the ékuele necklace is made, consisting of a chain and eight shells. When the chain is thrown onto the tray, the shells fall out in a new way each time, presenting a lashing and acute tongue of Ékuele (Fernandez 2014, p. 52).

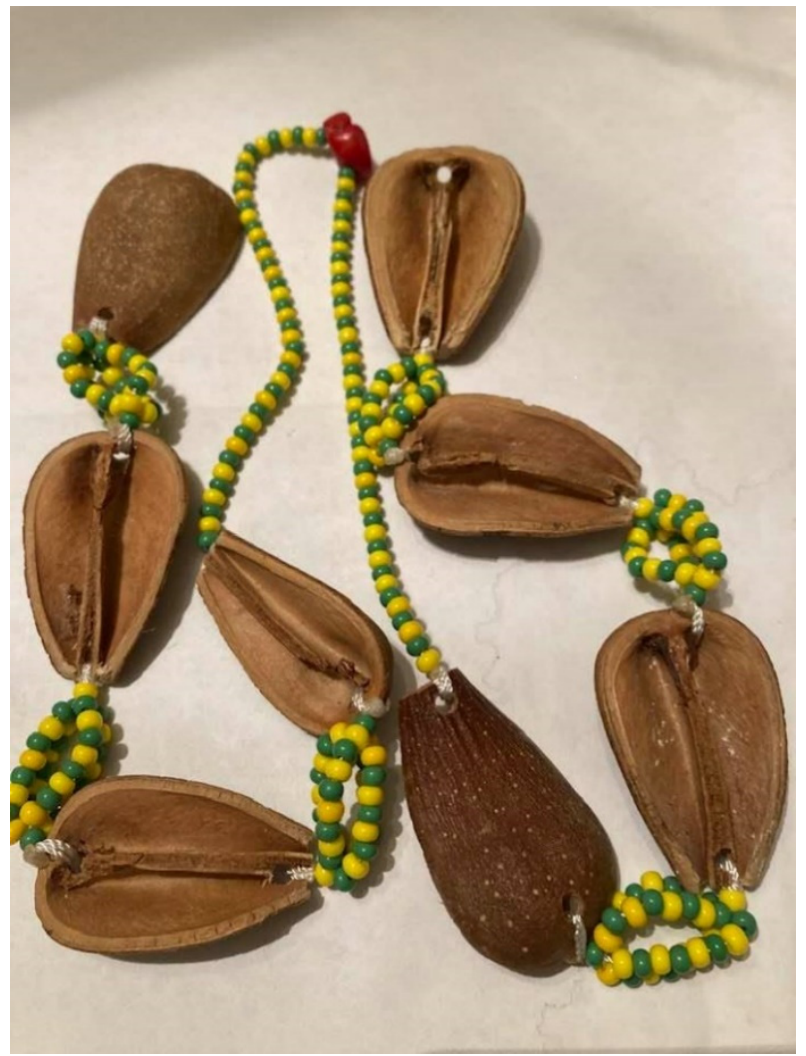

Figure 3. Ékuele chain, from the author's collection, green and yellow are colors of Orunmila, the deity of wisdom and divination. Interestingly, Orunmila is syncretized with Francis of Assisi, who is famous, in particular, for his ability to speak the language of birds and animals.

Michigan anthropologist Kristina Wirtz (2007a, 2007b) pointed out that the interpretation of Lukumi texts is often more like the practice of divination or fortune-telling than the actual "translation" of ritual texts:

“Cuban religious practitioners are engaged in 'divining' hidden meanings that relate to a sacred and transcendent Africa, based on Lucumí's status as an esoteric divine language and its capacity to store and transmit deep religious knowledge without revealing it." (Wirtz 2007a, p. 245) She further states that Santeros describe Lucumí as a divine language or the "tongue of the oricha" (la Lengua de Los oricha) highlighting its tremendous importance in maintaining ritual channels of communication with the orichas. "Lucumi texts such as songs and invocations are widely known among santeros, who can expertly perform them in rituals, whether or not they profess any understanding of a text's referential content. Indeed, only a few santeros feel able to offer translations or detailed explanations of even a few Lucumí texts, even though most santeros control a lexicon from a few dozen to hundreds of Lucumí words and phrases. Santeros thus display a bifurcated and very partial linguistic competence in Lucumí, in which they control a set of individual Lucumí words and phrases that have denotational (semantic) meaning and a set of phrases and longer texts that have primarily pragmatic 
and connotative meanings and often cannot even be segmented into individual words and translated." (Wirtz 2007a, p. 247).

When santeros were discussing isolated Lucumí words or phrases, they would provide a gloss in Spanish. However, for some expressions they would instead give pragmatic accounts of performative value or proper context of use, rather than a semantic definition. Wirtz (2007a, p. 249) notes that a santero explained the frequently used expression maferefun by providing examples of its use, even as she persisted in trying to pin down a simple gloss. She concluded, that santeros tend to focus on the performative and pragmatic values of many Lucumí expressions, rather than relying on purely denotational meanings, of which they may not be sure.

The Ifá system has been recognized by UNESCO as a "Masterpiece of the Oral and Intangible Heritage of Humanity." A rational and educated person would unlikely be serious about fortune-telling and divination. However, some people would argue that fortune-telling is just a certain classification of life situations and plots. Just as folk fairy tales and folklore plots have a certain classification, life itself has not so many plots that fit into the basis of 256 options.

Various methods of divination or fortune-telling usually rely either upon random occurrences (such as dice casting, the random position of thrown shells, random events in nature, etc.) or upon manifestations of the human subconscious, such as night dreams. According to Carl Jung, such random or unconscious occurrences constituting coincidences with other events may be viewed in the framework of "Synchronicity." The latter is a term now widely used in pseudo-scientific esoteric literature, but originally it was a part of Jungian psychoanalysis and meant coincidences and implied the situation when circumstances are meaningfully related but lack causal connection.

\subsection{Sacred Dances}

Dances play a central role in the Afro-Cuban culture in general and in the Santeria religion in particular. Almost every orisha (except the supreme deities) has its ritual dance.

While some researchers would speak about the "language of dance," for the purposes of this study dance as a semiotic system does not constitute a language, because it misses certain crucial elements of the natural language, such as the recursive (self-referencing) organization, hierarchy, and segmentation. On the other hand, the grammar of a ritual is a big topic of research, and "linguistic" descriptions, following the generative grammar approach have been proposed, for example, for the rituals of the Priestly Code in the Biblical Pentateuch.

Orisha dances serve several functions (see Figure 4). First, an orisha is visually represented by a dancer. Second, ritual dances are a way to achieve the state of trance, so that the dancer is possessed by an orisha, who descends upon the dancer (Hagedorn 2000, p. 102).

Graciela Chao Carbonero speaks in more detail about the ritual meaning of dancing in another lecture of the same cycle:

"As we can see that the same steps can be performed in both Elegua and Yemaya.

However, when we analyze the movements of the body, hands, the semantic meaning of the dance changes depending on the deity for whom they are performed." (Carbonero 2020).

The social Latin dances and, in particular, Afro-Cuban dances which are typically learned and performed in such institutions as clubs, Latin dance studios, or bars-bachata, salsa, kizomba, zouk, merengue, cumbia - are the so-called salon dances. They have European elements from ballroom dancing such as the closed position. Salsa has several styles, such as the usual linear salsa "on-one" ("Los Angeles style"), the more pretentious linear mamba "on-two" (Puerto Rican "New York-style" or Mambo). Cuban styles include circular Salsa Casino, Son, Timba, and Salsa with rumba elements. 


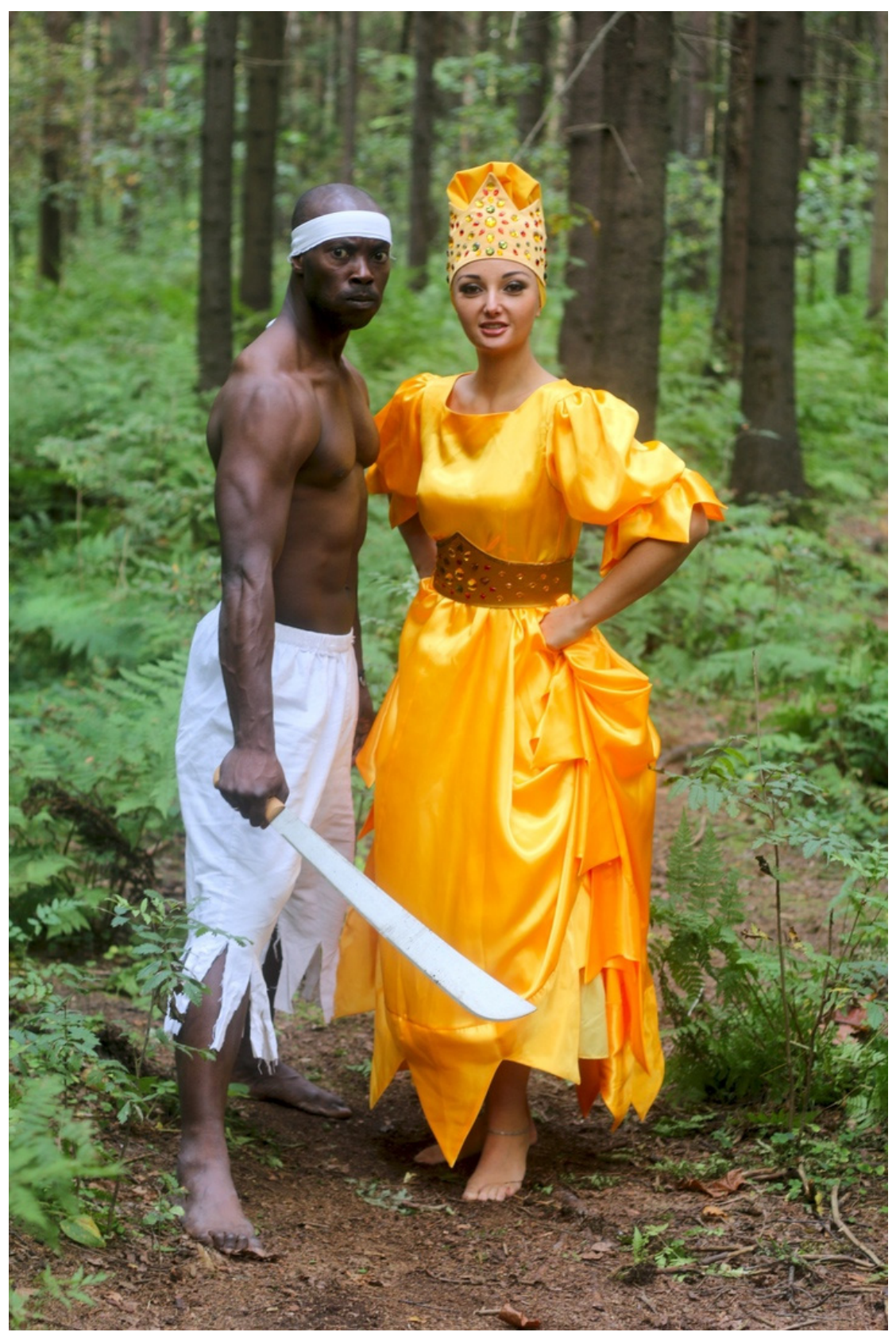

Figure 4. Dance teachers Iya Baval and Ildemar Rodriguez from the Latin Dance school Bembé (St. Petersburg, Russia) perform orisha dance (Ochun and Ogun).

However, these social and completely secular Latin dances borrow elements from the religious Santería orisha dances. All of the above are salon dances, but some of them contain African elements. Researcher Graciela Carbonero talks about this:

"We see that the movements of the body, hips, shoulders, characteristic of dances of African origin, are already included in the so-called salon dances, for example, in the habanero, mambo, cha-cha-cha, and our modern Salsa Casino ... ." (Carbonero 2020)

These elements come from African religions:

"In all of these religions, practically all, dancing and singing induce trance in some performers. After all, the goal is to establish a direct connection between the invoked deity and the human being." (Carbonero 2020) 
Katherine Hagedorn (2000, p. 107) discusses the difference between the religious and folkloric performances of the orisha dances, particularly, in the case of Eleguá possession dance:

"And if Eleguá had never arrived, much of the blame for his absence would have fallen on the musicians, as they are responsible for "bridging the gap between heaven and earth". If such a failure were to happen several times on Alberto's watch, he and his group would no longer be asked to play at toques, as his ability to bridge the gap (an important form of aché, or divine agency) would be assumed to be weak or dysfunctional. Such a judgment would deprive him and his group not only of money but, perhaps more importantly, of ritual status in the community. For this reason, Alberto and other "dual" musicians try to keep the two genres separate, in an attempt to protect and promote the divine possibilities of sacred intent. In fact, the two performance categories of "sacred" and "profane" do inform each other, which is what makes their often articulated distinction so compelling. According to Alberto and his group, the musicians use "the same" batá rhythms and songs in folkloric performances as they do in toques de santo. One could argue, then, that "real" and "folkloric" possession performances must occur along a continuum; indeed, one cannot exist without the other. Possession is compelling precisely because it is a performance, whether one believes it is divinely guided or not; what comes across is a sense of otherness, a separation from one's ordinary humanness. What differs, of course, is the intent of the performance, and the relative competence of the participants. The intent of a toque de santo is to bring down the oricha, an intent realized with the help of competent, ritually savvy participants." (Hagedorn 2000, p. 107)

Sacred and secular aspects of the orisha dances provide us with another example of bringing together the sacral and profane worlds and bridging the gap between them, similarly to the transition from the sacred language to the everyday language.

\section{Conclusions}

Judaism and Santería are very different religions, although they both have sacred languages (Hebrew and Lucumí, respectively) and both employ mechanisms of relating texts in a sacred language to everyday realities.

In Judaism, the translation from the Hebrew language to the everyday spoken language, such as Yiddish, was a mechanism that related the world of Scripture to the domain of everyday secular life. Choosing a word of Hebrew origin in Yiddish could also serve to reference the Biblical or traditional realities, similarly to incorporating a Biblical quotation or allusion, which we have seen in traditional epitaphs. Moreover, choosing the Hebrew consonant orthography over the Yiddish phonetic orthography could serve to relate to the sacred texts.

In Santería, where no written sacred texts existed, using words and phrases in the Lucumí language is a necessary part of rituals. The interpretation of these words in phrases through direct translation was not possible. Instead, the pragmatic meaning was employed. Moreover, divination was a tool for creating meanings, which related the sacred words with everyday occurrences (Table 1).

The relationship between the translation and the divination can be compared to the concepts of causality and the synchronicity postulated by Carl Jung. Synchronicity denotes the situation when circumstances are meaningfully related; however, they lack causal connection, and consequently, they are often interpreted as random coincidences. Divination is based upon random and unpredictable occurrences, while translation is rational and causal. 
Table 1. Comparison of Judaism and Santería.

\begin{tabular}{ccc}
\hline Feature & Judaism & Santería \\
\hline Bilingualism & Hebrew-Aramaic (or Hebrew-Yiddish) & Lucumí-Spanish \\
Meaning created by & Translation & Divination \\
Underlying process & Causality & Synchronicity \\
Used for & Prayer & Dance \\
In secular domain & Secular literature & Secular Afro-Cuban dances \\
Supreme power & Prohibition to depict the God & Supreme orishas do not dance \\
\hline
\end{tabular}

There are further differences and parallels in the attitudes towards textual and nontextual in these two religious traditions. In Santería, non-textual sacred rituals, such as dances of the Orishas, play a central role, while in Judaism Hebrew prayers have a similar function. Both religious Afro-Cuban dances and Hebrew texts have complex relations with their secular counterparts. The secular Yiddish and Hebrew literature used many motifs, allusions, and language tools borrowed from the traditional religious literature. In the Afro-Cuban culture, secular dances, such as Salsa and Timba, borrowed many elements from the ritual dances. It is interesting to note, that the supreme deities of Santeria, such as Olodumare, Olorun and Olofi do not have any dance. This can be compared with the Biblical prohibition to the description of the supreme God "by graven images".

Funding: This research received no external funding.

Institutional Review Board Statement: Not applicable.

Informed Consent Statement: Informed consent was obtained from all subjects involved.

Data Availability Statement: Not applicable.

Acknowledgments: The author thanks Inga Rekshan and Santera Iya Baval, both from the Bembé Latin dance school (St. Petersburg, Russia) for various discussions related to Santería and AfroCuban dances and Eleguá for Abre Caminos.

Conflicts of Interest: The author declares no conflict of interest.

\section{Notes}

1 While grammatically correct vocalization would be Leshon ha-Qodesh with shwa in status constructus, the traditional spelling and pronunciation which influenced Yiddish pronunciation is with kamatz/kometz.

2 The "Seven African Powers" became a popular concept of Santería in the United States, while in Cuba sixteen orishas are recognized (Lefever 1996, p. 323) including such important orishas as Ochosi (responsible for justice) and Oya (responsible for winds and markets), who have their own dances.

3 Note that the actual contact between the Jewish and Santería traditions were very limited. Note that another Afro-Cuban diasporic religious tradition, Palo Monte Mayombe (Las Reglas de Congo), uses the term "Jewish", which referres to any unbaptized (or, simply, non-Christian) person or an "unbaptized" object intended for "black magic." This terminology is also employed in Santería (Bettelheim 2001, p. 43).

\section{References}

Bettelheim, Judith. 2001. Palo Monte Mayombe and Its Influence on Cuban Contemporary Art. African Arts 34: 36-49, 94-96. [CrossRef]

Bohak, Gideon. 2007. Ancient Jewish Magic: A History. Cambridge: Cambridge University Press.

Brandon, George. 1997. Santeria from Africa to the New World. Bloomington: Indiana University Press, p. 56.

Carbonero, Graciela Chao. 2020. Lectures on the History of Cuban Folk Dances. Available online: https://salsainrussian.ru/cikl-lekcijpo-istorii-kubinskix-narodnyx-tancev-grasiela-karbonero/ (accessed on 30 September 2021). (In Russian).

Clark, Mary Ann. 2001. No Hay Ningun Santo Aqui! (There Are No Saints Here!): Symbolic Language within Santería. Journal of the American Academy of Religion 69: 21-41. [CrossRef]

Concordia, Maria J. 2012. The Anagó Language of Cuba. Master's thesis, Florida International University, Miami, FL, USA.

Fernandez, Alexander. 2014. Odú in Motion: Afro-Cuban Orisha Hermeneutics and Embodied Scholarship, Life Reflections of a Lukumí Priest. Master's thesis, Florida International University, Miami, FL, USA.

González-Wippler, Migene. 2002. Santeria: The Religion: Faith, Rites, Magic. St. Paul: Llewellyn Publications. 
Hagedorn, Katherine J. 2000. Bringing Down the Santo: An Analysis of Possession Performance in Afro-Cuban Santería. The World of Music 42: 99-113.

Lefever, Harry G. 1996. When the Saints Go Riding In: Santería in Cuba and the United States. Journal for the Scientific Study of Religion 35: 318-30. [CrossRef]

Lipsky, John. 1987. On the Construction ta + Infinitive in Caribbean Bozal Spanish. Romance Philology 40: 431-50.

Miller, Michael T. 2016. The Name of God in Jewish Thought A Philosophical Analysis of Mystical Traditions from Apocalyptic to Kabbalah. London: Routledge.

Nosonovsky, Michael. 1999. Hebrew epitaphs of the 16th century from Ukraine. In Monuments of Culture: New Discoveries - 1998. Moscow: Nauka, pp. 16-27.

Nosonovsky, Michael. 2008a. The scholastic lexicon in Ashkenazi Hebrew and orthography. Pinkas Journal of the Culture and History of East European Jewry Vilnius: Zara 2: 53-76.

Nosonovsky, Michael. 2008b. Old Jewish Cemeteries in Ukraine: History, Monuments, Epitaphs. In The Euro-Asian Jewish Yearbook5768 (2007/2008). Moscow: Pallada, pp. 237-61.

Nosonovsky, Michael. 2009. Folk beliefs, mystics and superstitions in Ashkenazi and Karaite tombstone inscriptions from Ukraine. Markers 26: 120-47.

Nosonovsky, Michael. 2017. Connecting Sacred and Mundane: From Bilingualism to Hermeneutics in Hebrew Epitaphs. Studia Humana 6: 96-106. [CrossRef]

Shapira, Dan. 2010. Yiddish-German, Slavic, or Oriental? Journal of Black Sea Studies 6: 127-40.

Villepastour, Amanda. 2011. The legacy of Ortiz's Yorubization of Lucumí Translation as transculturation. HAU: Journal of Ethnographic Theory 11: 1. [CrossRef]

Villepastour, Amanda. 2019. The Cuban lexicon Lucumí and African language Yoruba: Musical and historical connections. In Handbook of the Changing World Language Map. Edited by Stanley D. Brunn. Dordrecht: Springer. [CrossRef]

Weinreich, Max. 2008. History of the Yiddish Language. New Haven: Yale University Press.

Wirtz, Kristina. 2007a. Divining the Past: The Linguistic Reconstruction of 'African' Roots in Diasporic Ritual Registers and Songs. Journal of Religion in Africa 37: 242-74. [CrossRef]

Wirtz, Kristina. 2007b. How Diasporic Religious Communities Remember: Learning to Speak the "Tongue of the Oricha" in Santería. American Ethnologist 34: 108-26. [CrossRef]

Wirtz, Kristina. 2014. Performing Afro-Cuba: Image, Voice, Spectacle in the Making of Race and History. Chicago: University of Chicago Press. 